\title{
A study on relationship between electronic banking and liquidity management on Iranian banks
}

\author{
Hassan Ghodrati and Masoumeh Soleimani khah*
}

Department of Management and Accounting, Kashan Branch, IsIamic Azad University, Kashan, Iran

\begin{tabular}{l}
\hline C H R O N I C L E \\
\hline Article history: \\
Received December 28, 2013 \\
Received in revised format April \\
152014 \\
Accepted April 222014 \\
Available online \\
April 26 2014 \\
\hline Keywords: \\
Electronic Banking \\
Liquidity Management \\
Liquidity Risk \\
Liquidity ratios
\end{tabular}
\begin{abstract}
A B S T R A C T
E-banking has been extensively developed in recent decades and most banks need to have such services in their daily activities. Therefore, it is necessary that banks do a better management on banks' liquidity risks. Electronic banking and the expansion of its scale from POSs and ATMs to telephone banking, mobile banking and internet banking have increased banking transactions, significantly. The purpose of this investigation is to evaluate the relationship between the development of e-banking and liquidity management using liquidity ratios. The focus of this investigation has been on the amounts of transaction of ATM machines, POSs and PIN PADs as the most important means of electronic banking. In this respect, the data obtained from 14 private and public bank representatives of banking system over the period 2007-2012 are considered. Our survey indicates that the characteristics of electronic banking significantly influence on liquidity.
\end{abstract}

\section{Introduction}

Electronic banking is the use of information and communication technologies in banks to provide customers using their facilities without any need for physical presence in branch banking operations (Ghasemi, 2012). Despite the fact that internet banking has been widely implemented, there are still many challenges on optimally using these services (Maleki \& Akbari, 2010). Electronic banking can be exploited to measure parameters such as different kinds of cards issued, the number of ATM transactions per capita per one million people and the number of different instruments used. Banks as financial institutions naturally react very quickly to any change in the economic and technological environment. Largest banks as financial intermediaries play essential role in financing economic enterprises (Eghtesad Novin Bank, 2008).

The main objectives of the overall liquidity management of banks include the bank's liquidity position in the last analysis, forecast future needs, resources and methods to design the structure of bank assets (Bessis, 2011). "Liquidity Management" is one of the fundamental concepts in risk

*Corresponding author.

E-mail addresses: massi_sol@yahoo.com (M. Soleimani Khah) 
management institutions and the concept of bank "liquidity" is described as the short run ability of commercial banks to service deposit withdrawals and loan requests (Lucket, 1980; Souri \& Vesal, 2008). In terms of Islamic banking, liquidity management increases bank's ability to mobilize resources and to provide scheduling associated with legitimate requests (Yeager \& Seitz, 1989). According to Islamic banks, the interest rate should be prohibited (Souri \& Vesal, 2008).

Liquidity risk is the risk arising from the lack of necessary liquidity to cover short-term liabilities and fund unexpected output (Hemmati, et al., 2011). The primary reason of liquidity risk is that most sources of banks are provided through short-term deposits (Eghtesad Novin Bank Risk Study Team, 2008). Islamic economic thinking in the way of economic behavior calls upon the parties while sharing the benefits; both sides accept responsibility for the possible losses (Ghasemi Armaki \& Bahrololoum, 2006). In Islamic banking, liquidity risk can be divided into two cases: 1) lack of liquidity, and 2) lack of access to finance (Amr el Tiby, 2010). In other words, a recent innovation in the financial system has led to uncertainty in the supply of liquidity.

The main objective of this study is to find out the relationship between E-banking and liquidity management in Iranian banks.

\section{Review of literature}

Saghafy and Saif (2005) tried to identify and to measure financial ratios and fundamental economic variables influencing the health and stability of the banking system in Iran. They showed that the above-mentioned variables could influence on the health and the stability of the banks. Rostami and Qeydarpoor (2007) performed a comparative study on payment systems in Iran with CPSS principles. Souri and Vesal (2008) reviewed the organizational structure, liquidity management tools and systems for measuring and monitoring liquidity as a component of liquidity management banks have in common. The results showed that the first step in managing liquidity was to set up liquidity risk measurement system.

Rostamian and Haji Babai (2009) performed a survey on Saman bank liquidity risk to test the Cox Stewart and based on value-at-risk models over the period 2002-2007. They showed that liquidity risk during the period under review was downside. Mousavian and Kavand (2010) by using descriptive method showed that Islamic banks, due to the lack of adequate tools to manage liquidity, maintain a high volume of liquidity, which creates a high opportunity cost for them. Darabi and Molaii (2011) examined the effect of macroeconomic variables including liquidity, inflation, maintaining the capital and GDP on the Mellat bank's profitability over the period 2005-2009. They showed a positive and direct relationship between liquidity and profitability of the bank.

Hemmati and Ismail Nejad (2011) analyzed the Bank's liquidity gap in Sina bank. They showed that the liquidity gap in the bank was in good condition. Bank liquidity gap in the period following a year was positive and Intervals over a year due to maturities of long-term deposits was negative. Divandari et al. (2011) examined the effect of growth on deposit on loan rate, liquidity and investment returns in Mellat bank. The results showed that the bank's liquidity management issues were properly followed. Pashaii Pham (2011) assessed capital adequacy and risk management and analysis risk management in Islamic banking system and found lack of monitoring of the payment. He indicated that liquidity risk futures contracts, leases and partnerships was over in the conventional banking.

Hemmati et al. (2012) revealed that size of liquidity and degree of annual growth were influenced by monetary base and liquidity multiplier coefficient. Gougerdchian and Mir Hashemi Naeini (2013) investigated liquidity buy, conformity of cash flow of liquid assets, liabilities, and accounting exchanges of 20 Iranian banks over the period 2001-2009. Ahmadian (2013) evaluated and compared the performance of Iranian banks over the period 2010-2011 based on indicators of capital adequacy, asset quality, profitability, liquidity and other financial ratios. They showed that private banks with 
85\% loan to deposit ratio decreased liquidity risk management and better use of resources and worked.

Mihalcescu et al. (2008) assessed risk and innovation in electronic banking. They showed that the banks reduced their overall costs in two ways: by minimizing cost of processing transactions and increase on the numbers of branches that are required. Malhotra and Singh (2009) examined the effects of electronic banking on performance and risk in the banking industry in India.

Bordeleau and Graham (2010) analyzed the relationship between liquid assets holdings and profitability for a panel of Canadian and U.S. banks over the period 1997-2009. The results showed that profitability was improved for banks that hold some liquid assets. Yang et al. (2009) performed a comparative study on e-banking services among the young consumers between two nations of China and USA. According to the results of this study, the factors affecting the development of e-banking were product diversification, reduce costs, provide 24-hour banking services etc.

Bate and Kamil (2010) investigated the effect of electronic commerce on banking development and identified the economic prospects of e-banking and evaluated its advantages compared with the existing system. The results showed that electronic banking was an opportunity for banks. Munteanu (2012) identified the factors that influence bank liquidity through a multiple regression model, over a panel of commercial banks in Romania during the pre-crisis years observed separately over the crisis period 2008-2010. The results showed that the crisis brought substantial changes also over the structure of bank liquidity determinants.

Salman (2013) evaluated with using three measures of liquidity including the Liquid Assets to Total Assets Ratio, Financing to Deposit Ratio and Maturity Gap. They analyzed the state of liquidity and the risk management practices of Islamic banks across countries and regions and compared them with conventional banks. Results indicated that the business model of Islamic banking was changing over the time and moving in a direction where it was acquiring more liquidity risk. Agbada and Osuji (2013) explored the efficacy of liquidity management and banking performance in Nigeria. The study buttresses the fact that efficient liquidity management could significantly influence returns on capital employed by a bank and as well impact positively on the bank's profitability and thus its stability.

\section{Research questions}

As random sampling and descriptive inferential techniques were used in the study, the purpose of the study was to answer the following questions:

The main question:

- What is the relationship between development of e-banking and liquidity management?

Secondary research questions:

1. What is the relationship between development of e-banking and liquid assets ratio?

2. What is the relationship between development of e-banking and liquidity gap ratio?

3. What is the relationship between development of e-banking and liquid assets to customer and S-T funding ratio?

4. What is the relationship between development of e-banking and interbank ratio?

\section{Methodology}

The present study is an applied research with respect to the purpose, descriptive with regard to the use of inferential statistics, and post-events with regard to its direction. The population include the Iranian 
public and private banks over the period 2007-2011 where their information were available and consists of 14 banks. In this study, we used the parameters and statistical charts to describe the results of correlation analysis and linear regression methods to analyze complex data and relationships between variables. Fig. 1 shows the proposed study of this paper.

Dependent Variable

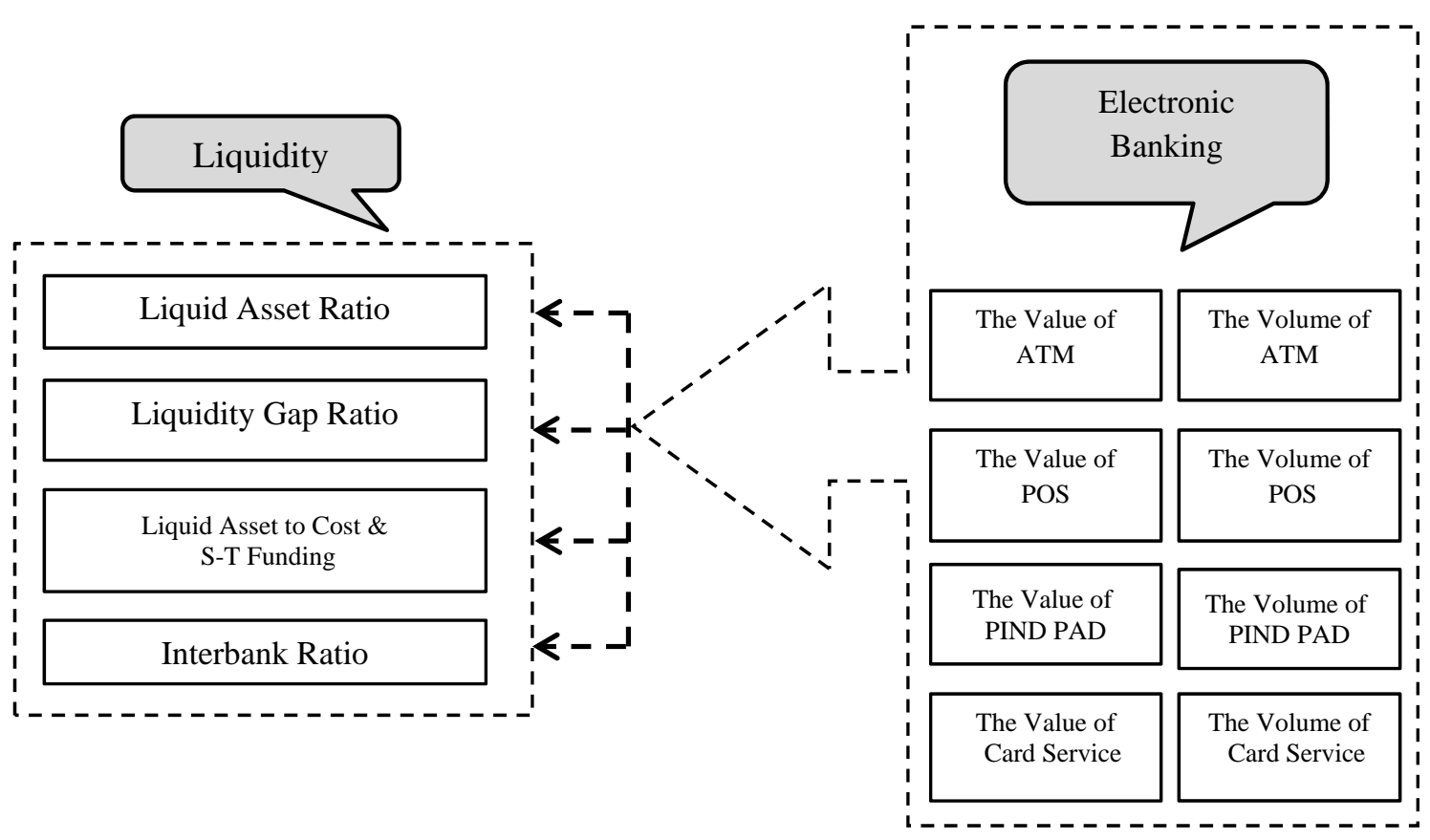

Fig. 1. The proposed study

In terms of a mathematical model, the following regression model is used in this study. The regression model is a deterministic mathematical model:

$$
\begin{aligned}
& Y_{j t}=\alpha+X_{i t}^{\prime} \beta+\left(u_{i}+v_{i t}\right) \quad j=1, \ldots, 6 \quad \text { Number of dependent variables } \\
& i=1, \ldots, 6 \quad \text { Number of independent variables } \\
& t=2007, \ldots, 2012 \quad \text { The period }
\end{aligned}
$$

where $X$ presents the matrix of explanatory variables, $\boldsymbol{\beta}$ is the matrix of parameters and $Y$ is the matrix of independent variables. The subscript $i$ represents bank level observations and the subscript $t$ is associated with time in years. Moreover, $\mathbf{u}_{\mathbf{i}}$ and $\mathbf{v}_{\mathrm{it}}$ show individual effects between sections and elements of model disorder. After examining independent variables in the research model, according to the observed correlation matrix between them, there was a strong relationship among variables of average transaction amount and average number of transactions per unit. This strong relationship led to nonlinearity between independent variables. Therefore, only variables of the average transaction amount were used to determine the models, and transaction number variables were removed from the model. Independent and dependent variables and the final controls used in this study are demonstrated in Table 1. 
Table 1

Variables and calculating

\begin{tabular}{|c|c|c|c|}
\hline \multicolumn{4}{|c|}{$\begin{array}{l}\text { Label Name } \quad \text { Definitions } \\
\text { Dependent variables (liquidity) }\end{array}$} \\
\hline$Y_{1}$ & LQTTA & $\begin{array}{l}\text { Liquid assets to total } \\
\text { assets ratio }\end{array}$ & $\frac{\text { Liquidit Assets }}{\text { Total Assets }}$ \\
\hline$Y_{2}$ & $L Q G R$ & Liquidity gap ratio & $\begin{array}{l}\text { Liquidity Gap }=(\text { Total Assets }- \text { Total Liabilities })+(\text { Fixed Assets }- \text { Equity }) \\
\text { Liquidity Gap Ratio = Liquidity Gap / Total Assets }\end{array}$ \\
\hline$Y_{3}$ & $L Q T D F$ & $\begin{array}{l}\text { Liquid assets to } \\
\text { costumer\& } S-T \text { funding } \\
\text { ratio }\end{array}$ & $\frac{\text { Liquidit Assets }}{\text { Deposits and Short Term Funding }}$ \\
\hline$Y_{4}$ & INATINL & Interbank ratio & $\frac{\text { Interbank Assets }}{\text { Interbank Liabilities }}$ \\
\hline \multicolumn{4}{|c|}{ Independent variables (electronic banking) } \\
\hline$X_{1}$ & ValATM & $\begin{array}{l}\text { Average value of ATM } \\
\text { transactions }\end{array}$ & $\frac{\text { Total value of ATM transactioms }}{\text { Total number of ATMS }}$ \\
\hline$X_{2}$ & ValPOS & $\begin{array}{l}\text { Average value of POS } \\
\text { transactions }\end{array}$ & $\frac{\text { Total value of POS transactions }}{\text { Total number of POSS }}$ \\
\hline$X_{3}$ & ValPIN & $\begin{array}{l}\text { Average value of PIN PAD } \\
\text { transactions }\end{array}$ & $\frac{\text { Total value of PIN PAD transactions }}{\text { Total number of PIN PADs }}$ \\
\hline$X_{4}$ & ValCard & $\begin{array}{l}\text { Average value of Card bank } \\
\text { transactions }\end{array}$ & $\frac{\text { Total value of all machines transactions }}{\text { Total number of Cards }}$ \\
\hline \multicolumn{4}{|c|}{ The control variables } \\
\hline$C_{1}$ & $L T D$ & Loan to Deposit ratio & $\frac{\text { Loans }}{\text { Deposits }}$ \\
\hline$C_{2}$ & $\operatorname{Ln} A$ & Size bank & The natural log of the total assets \\
\hline $\mathrm{C}_{3}$ & DUMMY & Owner & Private Banks=1, Public Banks=0 \\
\hline
\end{tabular}

\section{Findings of the study}

Description of dependent and independent variables selected by the model are presented in Table 2 and Table 3.

\section{Table 2}

Statistical description of the dependent variables

\begin{tabular}{lcccc}
\hline Index & LQTTA & LQGR & LQTDF & INATINL \\
\hline Average & 0.195474 & 0.032931 & 0.258031 & 0.693127 \\
Median & 0.197479 & 0.029789 & 0.253133 & 0.408167 \\
Maximum & 0.315392 & 0.096235 & 0.975605 & 4.879434 \\
Minimum & 0.055122 & 0.004568 & 0.069697 & 0 \\
Standard deviation & 0.063714 & 0.018352 & 0.113139 & 0.860859 \\
Number of observations & 84 & 84 & 84 & 84 \\
Number of banks & 14 & 14 & 14 & 14 \\
\hline
\end{tabular}

\section{Table 3}

Statistical description of the independent variables

\begin{tabular}{lccccccc}
\hline Index & ValATM & ValPOS & ValPIN & ValCard & LTD & LnA & DUMMY \\
\hline Average & $8.88 \mathrm{E}+10$ & $7.88 \mathrm{E}+10$ & $7.73 \mathrm{E}+10$ & $2.34 \mathrm{E}+11$ & 1.22691 & 12.21527 & 0.52381 \\
Median & $3.06 \mathrm{E}+10$ & $9.64 \mathrm{E}+09$ & $1.49 \mathrm{E}+10$ & $7.86 \mathrm{E}+10$ & 0.917216 & 12.30309 & 1 \\
Maximum & $9.97 \mathrm{E}+11$ & $1.84 \mathrm{E}+12$ & $8.20 \mathrm{E}+11$ & $2.36 \mathrm{E}+12$ & 5.464698 & 13.9825 & 1 \\
Minimum & $1.01 \mathrm{E}+09$ & 0 & 0 & $1.25 \mathrm{E}+09$ & 0.716618 & 10.15561 & 0 \\
Standard deviation & $1.90 \mathrm{E}+11$ & $2.43 \mathrm{E}+11$ & $1.53 \mathrm{E}+11$ & $4.62 \mathrm{E}+11$ & 0.93288 & 0.922892 & 0.502432 \\
Number of observations & 84 & 84 & 84 & 84 & 84 & 84 & 84 \\
Number of banks & 14 & 14 & 14 & 14 & 14 & 14 & 14 \\
\hline
\end{tabular}

Based on the conducted calculations of variables description, average of liquidated assets ratio to total assets for all studied banks is about 19.5\%. Pasargard, Kar Afarin, and Saman Banks have devoted the highest degree of liquidated assets ratio to all assets to themselves respectively. Maskan, 
Keshavarzi, and Sanat-Madan Banks respectively have the least ratio of liquidated assets to total assets. It is noteworthy that three private banks have the highest value and three state banks have the lowest value. Average liquidity gap variable for a set of studied banks is about 3.3. The highest value of liquidity gap (6\%) belongs to Saderat Bank and the lowest one (1.3\%) belongs to Sanat-Madan Bank. Average index of liquidated assets ratio to Cost \& S-T funding for all banks is about 25.8\%. Average interbank finance ratio variable for all banks is about 0.693 . This value is about zero for Pasargard Bank. In other words, interbank liabilities of this bank are zero. The highest amount is associated with Saderat Bank (2.877). This amount indicated that interbank liabilities to the amount of interbank assets for Saderat Bank are about three times. Variable of average ATM transactions amount is 88834523809 Rials. Most of this belongs to Melli, Saderat, Tejarat, and Pasargad Banks. Sanat-Madan, Kar Afarin, and Parsian have devoted the lowest amount to themselves respectively. The highest average value of the average variable of POS transactions at the time of the study belongs to Mellat, Melli, and Saderat. Average amount of this variable equals 78785031039.741 Rials for all banks. Kar Afarin, Sanat-Madan, Maskan, and Refah respectively had the lowest average value of average variable of sales terminal transactions during the period of the study. Average variable of average amount of transactions in PIN PAD set is 77276438095.2381 for all studied banks. The highest average value of this variable is linked to Melli, Saderat, and Maskan Banks. The lowest average value of this variable belongs to Kar Afarin, Sanat-Madan, Saman, and Parsian Banks respectively. Average variable of average amount of transactions of bank cards is 235894047619.048 for all banks during the study. The highest value of this variable was devoted to Melli, Saderat, and Mellat banks and the lowest one to Kar Afarin, Sanat-Madan, and Saman banks.

Skewedness and drag coefficients were employed to investigate normality of variables used in model. Results are presented in Table 4.

\section{Table 4}

Evaluation for normality variables

\begin{tabular}{lcc}
\hline Variables & Coefficient of Skewedness & Kurtosis \\
\hline Liquid assets to total assets ratio & -0.36 & 2.62 \\
Liquidity gap ratio & 1.56 & 5.62 \\
Liquid assets to costumer \& S-T funding ratio & 2.95 & 20.36 \\
Interbank ratio & 2.56 & 10.74 \\
Average of value ATMs & 3.59 & 15.75 \\
Average of value POSs & 5.36 & 35.64 \\
Average of value PIN PADs & 3.08 & 13 \\
Average of value Cards & 3.07 & 11.94 \\
Loans to deposits ratio & 3.02 & 11.39 \\
Size bank & -0.22 & 2.24 \\
Owner & -0.10 & 1.01 \\
\hline
\end{tabular}

If the absolute values of the skewedness and drag coefficients become less than 0.1 , they follow normal distribution. If the absolute value of this coefficient is less than 0.5 and greater than 0.1 , skewedness and drag is mall but non-negligible. As observed in the table, except variable of bank size, other variables have many differences with normal distribution. Skewers and drag coefficients were employed to investigate normality of remaining models 1-4. Table 5 shows the results. According to calculations of Table 5, skewedness and drag coefficients for distribution of residuals in regression estimation models is greater than one tenth. This indicates that residuals do not follow normal distribution.

\section{Table 5}

Evaluation for normality distribution of residuals

\begin{tabular}{lcc}
\hline Description & Coefficient of skewers & Kurtosis \\
\hline The first model & 0.694 & 0.976 \\
The second model & 1.269 & 3.950 \\
The third model & 3.518 & 28.250 \\
The fourth model & 0.880 & 3.698 \\
\hline
\end{tabular}


Relationship between electronic banking development and LQTTA ratio: First, interaction between the variables has been studied. Table 6 demonstrates the relationship between variables by correlation coefficient. Elements of correlation coefficient table between variables to degree of interaction are shown in Table 6.

\section{Table 6}

Relationship between independent and dependent variables of the first model

\begin{tabular}{lccccccccc}
\hline Variables & LQTTA & ValATM & ValPOS & ValPIN & ValCard & LTD & LnA & DUMMY \\
\hline LQTTA & 1 & .061 & .124 & -.058 & .057 & -.535 & -.141 & .542 \\
ValATM & .061 & 1 & .587 & .861 & .948 & -.147 & .521 & -.040 \\
ValPOS & .124 & .587 & 1 & .362 & .775 & -.110 & .428 & .148 \\
ValPIN & -.058 & .861 & .362 & 1 & .844 & -.096 & .555 & -.236 \\
ValCard & .057 & .948 & .775 & .844 & 1 & -.141 & .587 & -.028 \\
LTD & -.535 & -.147 & -.110 & -.096 & -.141 & 1 & -.113 & -.409 \\
LnA & -.141 & .521 & .428 & .555 & .587 & -.113 & 1 & -.171 \\
Dummy & .542 & -.040 & .148 & -.236 & -.028 & -.409 & -.171 & 1 \\
\hline
\end{tabular}

As seen in Table 6, there is not a strong correlation between dependent variable and independent variables. However, correlation level of control and dependent variables is more. Generalized least squares (GLS) technique has been used to estimate the first model (Table 7).

\section{Table 7}

Relationship between electronic banking and LQTTA index

\begin{tabular}{lccc}
\hline Variables & Symbol & Coefficients & Standard deviation \\
\hline Intercept & C & 0.277011 & 0.016175 \\
Average value of ATM transactions & ValATM & $9.60 \mathrm{E}-14$ & $4.74 \mathrm{E}-14$ \\
Average value of POS transactions & ValPOS & $1.01 \mathrm{E}-13$ & $3.14 \mathrm{E}-14$ \\
Average value of PIN PAD transactions & ValPIN & $2.58 \mathrm{E}-13$ & $9.57 \mathrm{E}-14$ \\
Average value of Card bank transactions & ValCard & $-1.19 \mathrm{E}-13$ & $3.93 \mathrm{E}-14$ \\
Loan to Deposit ratio & LTD & -0.062750 & 0.010002 \\
Owner & DUMMY & -0.026594 & 0.007510 \\
\hline
\end{tabular}

$\mathrm{R}^{2}=0.983730$, Adjusted $\mathrm{R}^{2}=0.968235$

Based on the obtained results, variable of average amount of ATM transactions, variable of average amount of POS transactions, and average amount of PIN PAD transactions had a direct relationship with variable of liquidation assets ratio to total assets. The relationship of variable of average amount of bank cards transactions, ratio of loans to deposits, and type of bank ownership with variable of the ratio of liquidation assets to total assets is reverse. Statistic $\mathrm{R}^{2}$ of model is about $98 \%$ that indicates there is a nearly strong linear relationship between variables.

Relationship between electronic banking development and LQGR: Table 8 shows interaction of variables through Pearson correlation coefficients:

Table 8

Relationship between dependent and independent variables in the second model

\begin{tabular}{|c|c|c|c|c|c|c|c|c|}
\hline Variables & LQGR & ValATM & ValPOS & ValPIN & ValCard & LTD & $\operatorname{Ln} A$ & DUMMY \\
\hline LQGR & 1 & .394 & .173 & .407 & .368 & -.256 & .207 & -.145 \\
\hline ValATM & .394 & 1 & .587 & .861 & .948 & -.147 & .521 & -.040 \\
\hline ValPOS & .173 & .587 & 1 & .362 & .775 & -.110 & .428 & .148 \\
\hline ValPIN & .407 & .861 & .362 & 1 & .844 & -.096 & .555 & -.236 \\
\hline ValCard & .368 & .948 & .775 & .844 & 1 & -.141 & .587 & -.028 \\
\hline LTD & -.256 & -.147 & -.110 & -.096 & -.141 & 1 & -.113 & -.409 \\
\hline LnA & .207 & .521 & .428 & .555 & .587 & -.113 & 1 & -.171 \\
\hline Dummy & -.145 & -.040 & .148 & -.236 & -.028 & -.409 & -.171 & 1 \\
\hline
\end{tabular}

As shown in Table 8, correlation between variable of relative liquidation gap and explanatory variables is about $20-40 \%$. In other words, the correlation between liquidation gap and variables of electronic banking is not too high. Generalized least squares (GLS) were employed to determine the 
relationship between electronic banking development and liquidation index LQGR. Table 9 shows the results.

\section{Table 9}

The relationship between the development of e-banking and LQGR Index

\begin{tabular}{lccc}
\hline Variables & Symbol & Coefficients & Standard deviation \\
\hline Intercept & C & 0.234673 & 0.095243 \\
Average value of ATM transactions & ValATM & $3.59 \mathrm{E}-14$ & $4.06 \mathrm{E}-14$ \\
Average value of POS transactions & ValPOS & $1.19 \mathrm{E}-14$ & $2.35 \mathrm{E}-14$ \\
Average value of PIN PAD transactions & ValPIN & $-4.01 \mathrm{E}-14$ & $5.02 \mathrm{E}-14$ \\
Average value of Card bank transactions & ValCard & $-9.55 \mathrm{E}-15$ & $3.17 \mathrm{E}-14$ \\
Loan to Deposit ratio & LTD & 0.002582 & 0.001911 \\
Size bank & LOG(C) & -0.080119 & 0.038102 \\
Owner & DUMMY & -0.001808 & 0.002570 \\
\hline $\mathrm{R}^{2}=0.786234$, Adjusted $\mathrm{R}^{2}=0.692711$ & & & \\
\hline
\end{tabular}

According to the results, variable of average amount of ATM transactions and average amount of POS transactions maintain a direct relationship with the variable of liquidation gap, and the relationship of bank size variable has a reverse relationship with liquidation gap. In addition, variables of ownership type and ratio of deposits to loans have a reverse relationship with the liquidity gap variable.

Relationship between electronic banking development and LQTDF index: Pearson correlation coefficients were employed to estimate variables interaction (Table 10).

Table 10

The relationship between the dependent and independent variables in the third model

\begin{tabular}{lccccccccc}
\hline Variables & LQTDF & ValATM & ValPOS & ValPIN & ValCard & LTD & LnA & DUMMY \\
\hline LQTDF & 1 & -.007 & .033 & -.086 & -.018 & .033 & -.228 & .254 \\
ValATM & -.007 & 1 & .587 & .861 & .948 & -.147 & .521 & -.040 \\
ValPOS & .033 & .587 & 1 & .362 & .775 & -.110 & .428 & .148 \\
ValPIN & -.086 & .861 & .362 & 1 & .844 & -.096 & .555 & -.236 \\
ValCard & -.018 & .948 & .775 & .844 & 1 & -.141 & .587 & -.028 \\
LTD & .033 & -.147 & -.110 & -.096 & -.141 & 1 & -.113 & -.409 \\
LnA & -.228 & .521 & .428 & .555 & .587 & -.113 & 1 & -.171 \\
Dummy & .254 & -.040 & .148 & -.236 & -.028 & -.409 & -.171 & 1 \\
\hline
\end{tabular}

According to Table 10, correlation between variable of interbank finance ratio and independent variable is low. The highest value of correlation is 22.8 and 25.4 for variables of bank size and type of ownership, respectively. GLS was used to examine the relationship between electronic banking development and ratio of liquidity assets to clients and short term finance. Table 11 shows the results.

\section{Table 11}

The relationship between the development of e-banking and LQTDF Index

\begin{tabular}{lccc}
\hline Variables & Symbol & Coefficients & Standard deviation \\
\hline Intercept & C & -0.412049 & 0.347585 \\
Average value of ATM transactions & ValATM & $2.89 \mathrm{E}-13$ & $1.07 \mathrm{E}-13$ \\
Average value of POS transactions & ValPOS & $1.67 \mathrm{E}-13$ & $6.38 \mathrm{E}-14$ \\
Average value of PIN PAD transactions & ValPIN & $2.62 \mathrm{E}-13$ & $1.31 \mathrm{E}-13$ \\
Average value of Card bank transactions & ValCard & $-2.80 \mathrm{E}-13$ & $8.74 \mathrm{E}-14$ \\
Loan to Deposit ratio & LTD & 0.025297 & 0.032414 \\
Size bank & LOG(C) & 0.268288 & 0.140255 \\
Owner & DUMMY & -0.057178 & 0.016749 \\
\hline
\end{tabular}

$\mathrm{R}^{2}=0.909320$ Adjusted $\mathrm{R}^{2}=0.869647$

According to Table 11, average amount of ATM transactions and average amount of POS transactions, ratio of deposits to loans, and bank size have a direct relationship with variable of 
liquidated assets ratio to Cost \& S-T funding. In addition, there is a reverse relationship between average amount of bank cards transactions and type of ownership. Statistic $\mathrm{R}^{2}$ of the model is about $90 \%$ that indicates there is a relatively strong linear relationship between variables.

Relationship between electronic banking development and INATINL index: Pearson correlation coefficient was employed to investigate the interaction of variables and the results are shown in Table 12.

\section{Table 12}

The relationship between the dependent and independent variables in the fourth model

\begin{tabular}{cccccccccc}
\hline Variables & INATINL & ValATM & ValPOS & ValPIN & ValCard & LTD & LnA & DUMMY \\
\hline INATINL & 1 & .361 & .120 & .289 & .303 & .273 & .201 & -.076 \\
ValATM & .361 & 1 & .587 & .861 & .948 & -.147 & .521 & -.040 \\
ValPOS & .120 & .587 & 1 & .362 & .775 & -.110 & .428 & .148 \\
ValPIN & .289 & .861 & .362 & 1 & .844 & -.096 & .555 & -.236 \\
ValCard & .303 & .948 & .775 & .844 & 1 & -.141 & .587 & -.028 \\
LTD & .273 & -.147 & -.110 & -.096 & -.141 & 1 & -.113 & -.409 \\
LnA & .201 & .521 & .428 & .555 & .587 & -.113 & 1 & -.171 \\
Dummy & -.076 & -.040 & .148 & -.236 & -.028 & -.409 & -.171 & 1 \\
\hline
\end{tabular}

According to the results, there is no strong relationship between variable of interbank finance and type of ownership. Other explanatory variables have a relatively poor correlation with dependent variable. Relationship between variables is determined by the generalized least squares (Table 13).

\section{Table 13}

The relationship between the development of e-banking and INATINL Index

\begin{tabular}{lccc}
\hline Variables & Symbol & Coefficients & Standard deviation \\
\hline Intercept & C & 2.274514 & 2.065324 \\
Average value of ATM transactions & ValATM & $7.19 \mathrm{E}-14$ & $1.08 \mathrm{E}-12$ \\
Average value of POS transactions & ValPOS & $-1.21 \mathrm{E}-12$ & $2.11 \mathrm{E}-13$ \\
Average value of PIN PAD transactions & ValPIN & $-2.90 \mathrm{E}-12$ & $1.20 \mathrm{E}-12$ \\
Average value of Card bank transactions & ValCard & $1.41 \mathrm{E}-12$ & $2.86 \mathrm{E}-13$ \\
Loan to Deposit ratio & LTD & 0.181489 & 0.286142 \\
Size bank & LOG(C) & -0.746958 & 0.841587 \\
Owner & DUMMY & 0.090712 & 0.117822 \\
\hline $\mathrm{R}^{2}=0.842066$, Adjusted $\mathrm{R}^{2}=0.772969$ & & &
\end{tabular}

Results of the fourth model estimation in Table 13 indicates that variables of average amount of POS transactions, average amount of PIN PAD transactions, and average amount bank cards transactions respectively have a reverse, reverse, and direct relationship with interbank finance variable. Moreover, average amount of ATM transactions, ratio of loans to deposits, bank size, and type of ownership respectively have a direct, direct, reverse and direct relationship with interbank finance variable. Statistic $\mathrm{R}^{2}$ shows that independent variables explain about $84 \%$ of the dependent variable behavior.

\section{Conclusion}

Results of the study on the evaluation of relationship between electronic banking development and liquidity management on the basis of assets liquidity index via correlation analysis and regression suggested that:

- There is a direct relationship between variable of average amount of ATM transactions and variable of liquidated assets ratio to total assets.

- $\quad$ There is a direct relationship between variable of average amount of POS transactions and variable of liquidated assets ratio to total assets.

- There is a direct relationship between variable of average amount of PIN PAD transactions and variable of liquidated assets ratio to total assets. 
- $\quad$ There is a reverse relationship between average amount of bank cards transactions and variable of liquidated assets ratio to total assets.

With regard to the findings of the first model, there is a relatively strong linear relationship between electronic banking development and variable of liquidated assets ratio to total assets.

Evaluation of the relationship between electronic banking development and relative liquidity gap as an index to measure liquidity management indicated that:

- There is a direct relationship between variable of average amount of ATM transactions and variable of liquidity gap ratio.

- $\quad$ There is a direct relationship between variable of average amount of POS transactions and variable of liquidity gap ratio.

- $\quad$ There is a reverse relationship between variable of average amount of PIN PAD transactions and variable of liquidity gap ratio.

- There is a reverse relationship between average amount of bank cards transactions and variable of liquidity gap ratio.

With regard to the findings of the second model, there is a significantly strong linear relationship between electronic banking development and variable of liquidity gap ratio. Evaluation of relationship between electronic banking development and ratio of liquid assets to Cost \& S-T funding as an index to measure banks liquidity management indicated that:

- There is a direct relationship between variable of average amount of ATM transactions and variable of liquid assets to Cost \& S-T funding ratio.

- There is a direct relationship between variable of average amount of POS transactions and variable of liquid assets to Cost \& S-T funding ratio.

- There is a direct relationship between variable of average amount of PIN PAD transactions and variable of liquid assets to Cost \& S-T funding ratio.

- There is a reverse relationship between average amount of bank cards transactions and variable of liquid assets to Cost \& S-T funding ratio.

With regard to the findings of the thirst model, there is a significantly strong linear relationship between electronic banking development and variable of liquid assets to Cost \& S-T funding ratio. Evaluation of the relationship between electronic banking development and relative interbank ratio as an index to measure liquidity management indicated that:

- There is a direct relationship between variable of average amount of ATM transactions and variable of interbank ratio.

- $\quad$ There is a reverse relationship between variable of average amount of POS transactions and variable of interbank ratio.

- $\quad$ There is a reverse relationship between variable of average amount of PIN PAD transactions and variable of interbank ratio.

- There is a direct relationship between average amount of bank cards transactions and variable of interbank ratio.

With regard to the findings of the forth model, there is a significantly strong linear relationship between electronic banking development and variable of interbank ratio.

\section{Acknowledgement}

The authors would like to thank the anonymous referees for constructive comments on earlier version of this paper. 


\section{References}

Ali, S. S. (2013). State of Liquidity Management in Islamic Financial Institutions. Islamic Economic Studies, 21(1), 63-98.

Agbada, A.O., \& Osuji, C.C. (2013). The efficacy of liquidity management and banking performance in Nigeria. International Review of Management and Business Research, 2(1), 223-233.

Ahmadian, A. (2013). The evaluation of Performance banking industry in Iran comparison years of 2010 and 2011. Institute for Monetary and Banking.

Bate M. A., \& Kami A. A. (2010). Ebanking of economical prospects in Bangladesh. Journal of Internet Banking and Commerce, 15(2).

Bessis, J. (2011). Risk management in banking. John Wiley \& Sons.

Bordeleau, É., \& Graham, C. (2010). The impact of liquidity on bank profitability(No. 2010, 38). Bank of Canada Working Paper.

Darabi R., \& Mowlaii, A. (2011). The effect of liquidity variables, inflation, preserve capital GDP on bank profitability. Journal of Financial Knowledge Exchange, 10, 139-182.

Divandari A., et al. (2011). A model for liquidity risk management of banks in times of crisis. Collection of twenty articles on Islamic Banking Conference, 133-158.

El Tiby, A. (2010). The nature of risk. Opinion: Risky Business, Dalam IBF,610.

Eghtesad Novin Bank Risk Study Team (2008). Asset liability management and liquidity risk in financial institutions' Fra Sokhan publishing, $1^{\text {th }}$, Page 217.

Ghasemi Armaki, A., \& Bahrol-olum, M. H. (2006). Risk management in Islamic banking. Proceedings of the Seventeenth Conference on Islamic Banking, 505-534.

Ghasemi, M. (2012). E-banking role in lowering the cost of banking services. Proceedings of the twenty-third Conference on Islamic banking, 63-64.

Gougerdchian A., \& Mir Hashemi Naeini S. (2013). Evaluate and test the performance of Iranian banking system liquidity management. Journal of Civil Engineering, 3(11), 1-22.

Hemmati, A. N., \& Ismail Nejad, M. (2011). Determined assets and liabilities management strategies based on the liquidity gap analysis. Proceedings of the Twenty-Second Conference on Islamic Banking, 117-131.

Hemmati, A., Ghasemi Ali Abadi, M., \& Zakeri, M. (2012). Assessment of the effects of e-banking on the monetary base and the money multiplier. Proceedings of the Twenty-Third Conference on Islamic Banking.

Lucket, D.G. (1980). Approaches to Bank Liquidity Management. Economic Review, Federal Reserve of Kansas City.

Maleki, M., \& Akbari P. (2010). Examines the role of e-banking in Iran. Journal of Banking and Economics, 112, 14-20.

Mihalcescu, C., Ciolacu, B., Pavel, F., \& Titrade, C. (2008). Risk and innovation in e-banking. Romanian Economic and Business Review, 3(2), 86-91.

Mohsen R., \& Qydarpour S. (2007). A Comparative Analysis of Iran's system of paying the ten principles of the International Committee of Payment and Settlement Systems. Proceedings of the Eighteenth Conference on Islamic Banking.

Munteanu, I. (2012). Bank liquidity and its determinants in Romania. Procedia Economics and Finance, 3, 993-998.

Malhotra, P., \& Singh, B. (2009). The impact of internet banking on bank performance and risk: The Indian experience. Eurasian Journal of Business and Economics, 2(4), 43-62.

Mohamad, M. T., \& Samsudin, M. L. How Islamic Banks of Malaysia Managing Liquidity? An Emphasis on Confronting Economic Cycles. 4(7), 253-263.

Mousavian, A., \& Kavand M. (2010). Liquidity management in Islamic Banking. Knowledge Economy, 1, 35-63.

Pashaii fam, R. (2011). Evaluation of Basel rules in the banking system, with emphasis on risk assessment ordering on Islamic contracts. Proceedings of the Twenty-Third Conference on Islamic Banking. 
Rostamian, F., \& Haji Babaei, F. (2009). The measurement of bank liquidity risk by using the Value at Risk (Case Study: Saman bank). Journal of financial accounting and auditing, 175-198.

Saghafy, A., \& Saif, V. (2005). Identification and measurement of financial ratios and fundamental economic variables affecting the health and stability of the banking system in Iran. Economic Journal, 17, 65-111.

Souri, D., \& Vesal M. (2008). New methods of financing and liquidity management in banks. Proceedings of the Nineteenth Conference on Islamic Banking, 231-247.

Yang, J., Cheng, L., \& Luo, X. (2009). A comparative study on e-banking services between China and USA. International Journal of Electronic Finance,3(3), 235-252.

Yeager, F. C., \& Seitz, N. (1982). Financial Institution Management: text and cases. Reston, Virginia: Reston Publishing Company. 